\title{
Analisis Penegakan Hukum terhadap Tindak Pidana Politik Uang dalam Pemilihan Kepala Daerah ditinjau dari Undang-Undang Nomor 10 Tahun 2016
}

\section{Analysis of Law Enforcement of Criminal Acts of Money Politics in Regional Head Elections Judging from Law Number 10/2016}

\author{
Ahmad Parlindungan \\ Program Studi Magister Hukum, Fakultas Hukum Universitas Islam Sumatera Utara, Indonesia
}

Diterima: Desember 2019; Disetujui: Desember 2019; Dipublish: Desember 2019

*Coresponding Email: ahmadparlindungan@gmail.com

\begin{abstract}
Abstrak
Pemilihan Kepala Daerah atau disingkat (Pilkada), sering terjadi kecurangan seperti yang terlihat pada salah satu putusan pengadilan no. 381 /Pid.Sus/2018.PN,Psp. Tentang politik uang. Politik uang adalah hasil dari memberi atau berjanji untuk menyuap seseorang dengan niat sehingga orang tersebut tidak melaksanakan haknya dengan cara tertentu selama pemilihan umum. Pemilihan kepala daerah adalah momentum utama demokrasi dalam pelaksanaan setiap pemilihan umum yang diadakan setiap pasangan calon mengharapkan tidak ada tindakan curang yang dilakukan oleh pasangan calon untuk menciptakan pemilihan kepala daerah yang kondusif. Untuk itu para pelaku politik uang dapat dimintai pertanggungjawaban atas tindakan mereka sebagaimana telah diatur dalam UU No.10 tahun 2016 tentang amandemen kedua atas UU No. 1 tahun 2015 tentang amandemen kedua atas UU nomor 1 tahun 2014 tentang pemilihan kepala daerah, sementara ada 25 jenis tindak pidana untuk pemilihan kepala daerah, sementara ada 5 pasal tentang tindak pidana pemilihan umum di KUHP. Pelanggaran pilkada terbagi menjadi dua, yaitu pelanggaran administrasi, pelanggaran pidana politik uang, dan perselisihan hasil pemilihan umum dalam hal ini pemilihan kepala daerah. Pelanggaran administratif dilaporkan ke komisi pemilihan dan diteruskan ke KPUD. Pelanggaran terhadap hasil pemilihan umum pidana dengan sistem peradilan pidana (polisi, jaksa penuntut umum, peradilan) sesuai dengan kode prosedur pidana, didahului dengan laporan dari publik atau pasangan calon kepada komite pengawas pemilu selambat-lambatnya tujuh hari setelah laporan tersebut dibuat. diterima, sementara pembubaran atas penyelamatan pemilihan kepala daerah yang awalnya ditangani oleh mahkamah agung diserahkan kepada mahkamah konstitusi.
\end{abstract}

Kata kunci: Politik Uang, Peraturan Tindak Pidana, Pemilihan Kepala Daerah.

\begin{abstract}
Regional Head Elections or abbreviated as (Pilkada), fraudulencies are often occurs as seen in one of the court verdict no. 381 /Pid.Sus/2018.PN,Psp. About money politics. Money politics is a from of giving or promising to bribe someone with the intention so thet the person does not carry out his righs in certain way during the general election. The regional head election is a main momentum of democracy in the implementation of each general election be held every pair of candidates expects no fraudulent acts carried out by the candidate pairs in order to create a conducive regional head general election. Therefor money politic perpetrators can be held accountable for their action as is have been regulated in Law No.10 of 2016 concerning the second amendement to Law No. 1 of 2015 concerning the second amendment to law number 1 of 2014 concerning the election of regional heads, while there are 25 types of criminal acts for the election of regional heads, while there are 5 articles concerning on criminal acts of general election in KUHP. Pilkada violations are divided into there, which are administrative violation, criminal violations of money politics, and disputes over the result of general elections in this case the election of regional heads. Administrative violations were reported to the electoral commission and forwarded to KPUD. Violations of general election criminal proceeds with the criminal justice system (police, public prosecutor, judiciary) in accordance with the criminal procedure code, preceded by report from thev public or candidate pairs to the election supervisory committee no later than seven days after the report is received, while disputer over the resoult of the regional head elections originally handled by the supreme court was handed over to the constitional court.
\end{abstract}

Keyword: Money Politics, The Regulation of Criminal Acts, Election of Regional Heads.

How to Cite: Parlindungan, A. (2019). Analisis Penegakan Hukum terhadap Tindak Pidana Politik Uang dalam Pemilihan Kepala Daerah (Pilkada) Ditinjau Dari Undang-Undang Nomor 10 Tahun 2016. Journal of Education, Humaniora and Social Sciences (JEHSS). 2 (2): 335-351. 


\section{PENDAHULUAN}

Pilkada merupakan rezim pemerintah daerah pada pasal 22E ayat (1) dan ayat (2) UUDNRI Tahun 1945 di katakan bahwa pemilhan umum di laksanakan secara langsung, umum, bebas, rahasia, jujur dan adil setiap lima tahun sekali dan di selenggarakan untuk memilih anggota DPR, DPD, Presiden dan wakil Presiden serta DPRD bertolak dari penjabaran Pasal 22E ayat (1) dan (2) dimaksud, dapat dipahami bahwa pilkada bukan merupakan bagian dari rezim pemilihan umum (pemilu) karena rezim pemilu hanya untuk memilih anggota DPR, DPD, Presiden, dan Wakil Presiden serta DPRD, tidak termasuk di dalamnya memilih Kepala Daerah (Gubernur, Bupati, dan Walikota).

Aturan mengenai pilkada secara eksplisit diatur dalam bab tersendiri yaitu Bab VI tentang Pemerintah Daerah. Pasal 18 ayat (4) UUDNRI Tahun 1945 menyatakan secara tegas bahwa: "Gubernur, Bupati, dan Walikota masing-masing sebagai kepala pemerintahan daerah provinsi, kabupaten, dan kota dipilih secara demokratis". Arti demokratis disini dapat di maknai sebagai pemilihan secara langsung oleh rakyat maupun tidak langsung lewat DPRD. Oleh karena Pasal 18 ayat (4) UUDNRI Tahun 1945 tentang pemilihan kepada daerah tersebut berada di bawah bab tentang Pemerintah Daerah, maka pengaturan pilkada tersebut dalam pelaksanaannya dimuat dalam undang-undang yang termasuk dalam rezim Pemerintahan Daerah. Pilkada sebagai bagian dari rezim Pemerintahan Daerah, dalam penjabarannya oleh UU No. 22 Tahun 1999 (UU Pemerintahan Daerah sebelumnya) tidak dilaksanakan dalam satu proses pemilihan langsung oleh rakyat, melainkan dilakukan oleh Dewan Perwakilan Rakyat (DPRD).

Sejak berlakunya UU No. 32 Tahun 2004 tentang Pemerintahan Daerah, telah merubah sistem pemilihan Kepala Daerah dari pemilihan melalui DPRD menjadi pemilihan langsung oleh rakyat sebagaimana disebutkan dalam Pasal 56 ayat (1) yang berbunyi: "Kepala daerah dan wakil kepala daerah dipilih dalam satu pasangan calon yang dilaksanakan secara demokratis berdasarkan asas langsung, umum, bebas, rahasia, jujur, dan adil".

Demokrasi sebagai dasar hidup bernegara memberi pengertian bahwa pada tingkat terakhir rakyat memberikan ketentuan dalam masalah-masalah pokok mengenai kehidupannya, termasuk dalam menilai kebijakan negara, karena kebijakan tersebut menentukan kehidupan rakyat (Moh, Mahfud MD, 1998). pemilihan umum (pemilu) 
merupakan instrumen penting dalam demokrasi yang menganut sistem perwakilan. Pemilu berfungsi sebagai alat penyaring bagi "politikus-politikus" yang akan mewakili dan membawa suara rakyat di dalam lembaga perwakilan, mereka yang terpilih dianggap sebagai orang atau kelompok yang mempunyai kemampuan atau kewajiban untuk bicara dan bertindak atas nama suatu kelompok yang lebih besar melalui partai politik (parpol). Oleh sebab itu, adanya partai politik merupakan keharusan dalam kehidupan politik modern yang demokratis. Hal itu dimaksudkan untuk mengaktifkan dan memobilisasi rakyat, mewakili kepentingan tertentu, memberi jalan kompromi bagi pendapat yang berlawanan, serta menyediakan sarana suksesi kepemimpinan politik secara sah dan damai (Moh, Mahfud MD, 2013).

Pada Pemilihan Kepala Daerah (Pemilukada), yang dilaksanakan dalam rentang waktu lima tahun merupakan suatu sarana untuk memilih kepala daerah yang berkualitas dan memiliki dedikasi. Hal ini penting, sebab melalui proses pemilukada akan menghasilkan seorang calon pemimpin dalam masa lima tahun ke depan untuk menentukan pembangunan di suatu daerah, baik itu tingkat provinsi maupun di kabupaten/kota.

Pemilihan umum hampir tidak mungkin dilaksanakan tanpa kehadiran partaipartai politik di tengah masyarakat. Keberadaan partai juga merupakan salah satu wujud nyata pelaksanaan asas kedaulatan rakyat. Sebab dengan partai-partai politik itulah segala aspirasi rakyat yang kedaulatan berada di tangan rakyat, maka kekuasaan harus di bangun dari bawah (buttum up).

Terkait dengan buruknya asumsi terhadap praktek politik dan politikus, Andi Setiadi dalam bukunya "Politik Harapan Palsu" menyatakan: "politik itu bukan soal kebenaran, tapi kepentingan. Politik itu bukan soal siapa "menghasilkan" apa, tapi soal siapa "mendapatkan" apa. Itulah sebabnya, muncul adagium politik yang begitu populer terhadap politik, "Tiada kawan atau lawan yang abadi, yang ada hanyalah kepentingan abadi" (Setiadi, 2013).

Menguraikan makna dari kata bijak tersebut di atas, hampir semua para calon pemimpin hanya mampu berjanji, sedangkan implementasi apa yang disampaikan pada saat kampanye sepertinya bagaikan angin lalu yang berhembus begitu saja. Dampaknya masyarakat mulai apatis, kepedulian masyarakat terhadap pelaksanaan pemilukada 
tidak lagi seperti diawal-awal tahun pelaksanaan pesta demokrasi di Indonesia Nurfitriani, Hamrun \& Ahmad, 2017; Putra, 2018; Suharyanto, 2014).

Kurangnya antusiasme masyarakat terhadap pelaksanaan pemilu ditandai dengan rendahnya minat masyarakat untuk menggunakan hak pilihnya. Sedangkan dinamika politik berjalan begitu monoton dan sangat melelahkan. Ibarat sebuah permainan, para pemegang kekuasan negara selalu mengatasnamakanrakyat sama sekali tidak menargetkan apapun selain kepentingan-kepentingan pragmatis yang menjijikan. demokrasi dan pluralisme, misalnya seakan menjadi sebuah istilah yang sengaja diadopsi untuk menutupi gelombang ketidakadilan. Kenyataan tersebut akan merobohkan bangunan politik di bangsa ini, sebab semakin terkikisnya komitmen kebangsaan yang kuat dalam diri para pejabat. Tidak adanya komitmen kebangsaan yang kuat dari para calon pemimpin dan para pejabat di negeri ini terlihat dari sikap yang selalu memosisikan diri sebagai yang "dilayani", maka rasa memiliki (sense of belonging) terhadap negara ini semakin terkikis.

Ketika hal itu terjadi, akan berdampak pada menurunnya partisipasi politik rakyat, sehingga pada saat pemilu digelar rakyat enggan turut serta. Hal ini terjadi karena trauma politik yang berkepanjangan yang dialami. Sebab, tidak ada lagi yang bisa diharapkan selain antraksi politik yang menjemukan, dimana pertarungan kepentingan antara para politikus menjadi suatu pemandangan yang sangat membosankan. Sementara itu, cita-cita luhur untuk membawa bangsa ini keluar dari cengkeraman krisis multidimensi, cenderung dilupakan (Setiadi, 2013). Ketidak mampuan para calon kepala daerah dalam pilkada untuk mempengaruhi rakyat dengan program-program yang menyentuh langsung pada nadi masyarakat kecil, membuat sebagian calon kepala daerah pada saat pemilukada menggunakan politik uang dalam menggait suara. Politik uang dirasakan cara instan yang dapat dilakukan untuk menarik simpati rakyat.

Praktek politik uang dalam pelaksanaan pilkada, ketentuan Undang-Undang Nomor 10 Tahun 2016 Tentang Perubahan Kedua Atas Undang-Undang Nomor 1 Tahun 2015 Tentang Penetapan Peraturan Pemerintah Pengganti Undang-Undang Nomor 1 Tahun 2014 Tentang Pemilihan Gubernur, Bupati dan Walikota Menjadi Undang-Undang (selanjutnya disebut Undang-Undang Nomor 10 Tahun 2016 Tentang Pilkada), telah menentukan bahwa politik uang sebagai perbuatan pidana yang diancam dengan pidana penjara dan Denda. 
Vol 2, No. 2, Desember 2019, DOI: https://doi.org/10.34007/iehss.v2i2.108

Sebagai mana bunyi Pasal 187 A ayat (1) Undang-undang Nomor 10 Tahun 2016 Tentang Pemilihan Gubernur Bupati dan Walikota menyebutkan bahwa:

Setiap orang yang dengan sengaja melakukan perbuatan melawan hukum menjanjikan atau memberikan uang atau materi lainnya sebagai imbalan kepada warga negara Indonesia baik secara langsung ataupun tidak langsung untuk mempengaruhi pemilih agar tidak menggunakan hak pilih, menggunakan hak pilih dengan cara tertentu sehingga suara menjadi tidak sah, memilih calon tertentu, atau tidak memilih calon tertentu akan dipidana dengan pidana penjara paling singkat 36 (tiga puluh enam) bulan dan paling lama 72 (tujuh puluh dua) bulan dan denda paling sedikit rp 200.000.000,(dua ratus juta rupiah) dan paling banyak Rp.1.000.000.000,- (satu milyar rupiah).

Kemudian pada ayat (2) dinyatakan bahwa pidana yang sama diterapkan kepada pemilih yang dengan sengaja melakukan perbuatan melawan hukum menerima pemberian atau janji sebagaimana dimaksud pada ayat (1).

Politik uang merupakan berdasarkan Undang-Undang No. 10 Tahun 2016, merupakan suatu perbuatan yang dirumuskan sebagai delik atau tindak pidana pemilu. Oleh undang-undang, baik pemberi maupun penerima dari politik uang diancam dengan pidana.

Berkenaan dengan praktek politik uang yang dirumuskan sebagai delik pidana dalam Undang-Undang No. 10 Tahun 2016, maka logika hukumnya terhadap pelaku haruslah diproses sesuai sistem hukum yang berlaku, yakni diproses berdasarkan proses peradilan pidana. Dengan kata lain, aparat penegak hukum harus menindaklanjuti dan melakukan penegakan hukum terhadap setiap temuan praktek politik uang yang dalam pelaksanaan pemilu, khususnya dalam pemilukada.

Undang-undang nomor 10 Tahun 2016 Tentang Perubahan Kedua Atas UU nomor 1 Tahun 2015 Tentang penetapan Perpu No. 1 Tahun 2014 Tentang Pemilihan Gubernur, Bupati, Walikota pilkada mengatur sanksi pidana bagi pihak manapun yang menjalankan praktik politik uang, sanksi di atur dalam pasal 187 poin A orang yang terlibat politik uang sebagai pemberi bisa di penjara paling singkat 36 bulan dan paling lama 72 bulan, selain hukuman badan, pelaku juga di kenakan denda paling sedikit Rp 200 juta dan paling banyak Rp 1 milyar, Undang-undang ini hanya berlaku pada masa setelah penetapan atau masa kampanye sedangkan pada masa sosialisasi atau sebelum masa penetapan, calon yang melakukan Money Politic seperti memberi sapi atau mobil kepada 
masyarakat belum di atur di dalam Undang -Undang. Mestinya di atur karena secara sosialisasi jujur dan adil di dalam pilkada masih belum diterapkan hanya orang kaya saja yang bisa menang, jelas ini meracuni pemikiran masyarakat. Calon yang melakukan politik uang (Money Politic) otomatis dia akan mengembalikan dana politik pasti calon tersebut tidak mau rugi. Kampanye berlebihan di dalam pilkada seperti sebelum mendapatkan nomor undian tetapi sudah melakukan ketidakwajaran juga menjadi isu tersendiri.

Pada proses demokrasi level akar rumput (grass root), praktik money politic tumbuh subur. Karena dianggap suatu kewajaran, masyarakat tidak lagi peka terhadap bahayanya. Mereka membiarkannya, karena tidak merasa bahwa money politic normatif harus di jauhi. Segalanya berjalan dengan wajar. Kendati jelas terjadi money politic, dan hal itu diakui oleh kalangan masyarakat, namun tidak ada protes.

Budaya money politics merupakan hal lumrah dalam mayarakat. Fenomena money politics dalam masyarakat bisa dilihat secara langsung dalam proses pemilihan kepala desa atau lurah sebagai komponen terkecil dari pemerintahan Indonesia. Proses percalonan kepala desa sering kali tidak lepas dari penggunaan uang sebagai upaya menarik simpati warga. Dalam skala yang lebih luas, praktik money politics telah melibatkan hampir seluruh elemen sosial seperti pejabat, politisi, akademisi, pendidik, saudagar, bahkan kalangan agamawan sekalipun.

Dalam perspektif sosiologi politik, fenomena bantuan politis ini di pahami sebagai wujud sistem pertukaran sosial yang biasa terjadi dalam realitas permainan politik. Karena interaksi politik memang meniscayakan sikap seseorang untuk di penuhi oleh penggarapan timbal balik (reciprocity). Dengn kata lain, relasi resiprositas merupakan dasar bagi terciptanya sistem pertukaran sosial yang seimbang. Perilaku money politics, dalam konteks politik sekarang, sering kali diatas namakan sebagai bantuan, infaq, shadaqah, dan lain - lain. Pergeseran istilah, money politics ke dalam istilahan moral ini secara tidak langsung telah menghasilkan perlindungan secara sosial melalui norma kultural masyarakat yang memang melazimkan tindakan itu terjadi. Takkala masyarakat telah mengganggap sebagai tindakan lumrah, maka kekuatan legal formal hukum akan kesulitan untuk menjangkaunya. Karena itu di butuhkan kerangka kerja tafsir untuk memahami setiap makna yang tersimpan dibalik perilaku politik (political behavior) 
sehingga dapat memudahkan dalam pemisahan secara analitik antara pemberian yang sarat dengan nuanssa suap, dan pemberian dalam arti sesungguhnya sebagai bantuan.

Penegakan hukum terhadap praktek politik uang pada pemilukada, dapat dilihat dalam Putusan Register Perkara Nomor. 381/Pid. Sus/2018/PN.Psp. bahwa terpidana Nama Ramli tanjung. Pekerjaan pegawai Swasta telah terbukti secara sah dan meyakinkan bersalah melakukan tindak pidana. "Setiap orang yang dengan sengaja melakukan perbuatan melawan hukum menjanjikan atau memberikan uang atau materi lainnya sebagai imbalan kepada warga Negara Indonesia baik secara langsung maupun tidak langsung untuk mempengaruhi pemilih agar tidak menggunakan hak pilih, menggunakan hak pilih dngan cara tertentu sehingga suara menjadi tidak sah, memilih calon tertentu, atau tidak memilih calon tertentu" sebagaimana diatur dan diancam pidana dalam Pasal 73 ayat (4) jo Pasal 187-A ayat (1) UU RI No. 10 Tahun 2016.

Tentang Perubahan Kedua Atas Undang-Undang Nomor 1 Tahun 2015 Tentang Penetapan Peraturan Pemerintah Pengganti Undang-Undang Nomor 1 Tahun 2014 Tentang Pemilihan Gubernur, Bupati dan Walikota menjadi Undang-Undang.

Atas putusan Menjatuhkan pidana terhadap Terdakwa RAMLI TANJUNG dengan pidana penjara selama 48 (empat puluh delapan) bulan dan denda sebesar Rp.200.000.000,- (dua ratus juta rupiah) Subsidair 1 (satu) bulan kurungan. Menetapkan barang bukti berupa (tiga) amplop warna putih dalam keadaan terbuka yang berisikan uang kertas tukaran Rp.50.000,00 (lima puluh ribu rupiah).

\section{METODE PENELITIAN}

Konsep dalam penelitian adalah untuk menghubungkan dunia teori dan observasi, antara abstraksi dan realitas. Konsep dapat pula diartikan sebagai kata yang menyatakan abstrak yang digeneralisasikan dari hal-hal yang khusus, yang disebut dengan definisi operasional (Suryabrata, 1998). Menghindari terjadinya perbedaan pengertian tentang konsep yang dipakai dalam penelitian ini, perlu dikemukakan mengenai pengertian konsep yang akan digunakan, sebagai berikut: 1) Analisa menurut Kamus Besar Bahasa Indonesia adalah penyelidikan terhadap suatu peristiwa (karangan, perbuatan, dsb) untuk mengetahui keadaan yang sebenarnya (sebab-musabab, duduk perkaranya) dan lain sebagainya (Hasan, 2002). 2) Penegakan Hukum menurut Soerjono Soekanto adalah kegiatan menyerasikan hubungan nila-nilai yang terjabarkan dalam kaidah-kaidah 
mantap dan sikap tindak sebagai rangkaian penjabaran nilai tahap akhir. untuk menciptakan, memelihara dan mempertahankan kedamaian pergaulan hidup (Soekanto, 1998). Penegakan hukum dapat juga diartikan penyelenggarakan hukum oleh petugas penegak hukum dan oleh setiap orang yang mempunyai kepentingan sesuai dengan kewenangannya masing-masing menurut aturan hukum yang berlaku. Penegakan hukum yang dimaksudkan dalam penelitian tesis ini adalah penegakan hukum UndangUndang No. 10 Tahun 2016, berkenaan dengan tindak pidana politik uang yang terjadi dalam pemilukada.

Tindak Pidana menurut Moeljatno adalah perbuatan yang dilarang oleh suatu aturan hukum larangan mana disertai ancaman (sanksi) yang berupa pidana tertentu, bagi barang siapa melanggar larangan tersebut" (Moeljatno, 2000). Politik Uang menurut Indra Ismawan biasa diartikan sebagai upaya mempengaruhi perilaku orang dengan menggunakan imbalan tertentu. Ada pula yang mengartikan politik uang sebagai tindakan jual beli suara pada sebuah proses politik dan kekuasaan. Tindakan itu dapat terjadi dalam jangkauan (range) yang lebar, dari pemilihan kepala desa sampai pemilihan umum di suatu negara (Ismawan, 1999). Pemilukada adalah pemilihan Kepala Daerah yang diselenggarakan dalam jangka waktu 5 tahun sekali, yang meliputi pemilihan Gubernur dan Wakil Gubernur pada tingkat provinsi dan pemilihan Bupati/Wakil Bupati atau Walikota/Wakil Wali Kota di tingkat kabupaten/kota.

\section{HASIL DAN PEMBAHASAN}

\section{Batasan Tindak Pidana dalam Pemilihan Kepala Daerah}

Secara garis besar pelanggaran-pelanggaran dalam setiap tahapan pelaksanaan Pemilihan Kepala Daerah secara langsung dapat diklasifikasikan menjadi 3 (tiga) pelanggaran, yaitu Pelanggaranadministratif dan Pelanggaran pidana, dan Perselisihan hasil pemilihan umum. Meskipun dalam ketentuan UU No.10 Tahun 2016, Tentang Pemerintahan Daerah yang dijadikan dasar pelaksanaan Pemilihan Kepala Daerah secara langsung, adakalanya pelanggaran yang terjadi merupakan pelanggaran administratif saja, tetapi ada juga pelanggarantersebut selain merupakan pelanggaran administratif, juga merupakan pelanggaran pidana.

Yang dimaksud dengan pelanggaran pidana Pemilu dalam UU No. 10Tahun 2016 Jo UU No. 1 Tahun 2015 Tentang Pemerintahan Daerah sessungguhnya tidak berbeda 
dengan pengertian Tindak Pidana Pemilukadaatau pelanggaran pidana Pemilu seperti diatur dalam beberapa undang-undang Pemilu sebelumnya. Terkait pelanggaran pidana, UU No.10 Tahun 2016 Jo UU No. 1 Tahun 2015 Tentang Pemerintahan Daerah secara jelas mencantumkan sejumlah ketentuan pidana Pemilu dan menyertakan ancaman pidana saksi pidana yang pasti bagi pelakunya. Pelanggaran terhadap ketentuanketentuan pidana Pemilu yang diatur dalam undang-undang itulah yang disebut dengan pelanggaran pidana Pemilu (Santoso, 1987). Untuk menyesuaikan dengan nomenklatur hukum pidana, istilah 'Pelanggaran Pidana Pemilu' sebaiknya diganti dengan istilah 'Tindak Pidana Pemilu'.Penggantian istilah ini penting karena tindak pidana pemilu juga merupakan kejahatan yang harus dihukum berat karena menyangkut penggunaan hak pilih dan hak memilih warga negara, bukan sekadar pelanggaran yang berarti hanya menyimpang atau menyalahi ketentuan-ketentuan peraturan perundangan. Dengan demikian, tindak pidana berarti tindakan hukum yang melanggar ketentuan-ketentuan. Pelanggaran Pidana diproses dengan sistem Peradilan Pidana (Kepolisian, Penuntut Umum, Peradilan) sesuai dengan KUHAP, dengandiawali laporan masyarakat ataupun pasangan calon kepada panitia pengawas pemilihan selambat-lambatnya 7 (tujuh) hari sejak laporan diterima.

Terhadap pelanggaran administrasi Pemilu, UU No. 10 Tahun 2016 Jo UU No. 1Tahun 2015 Tentang Pemerintahan Daerah sama sekali tidak memberikan batasan yang jelas. Memang dikatakan bahwa yang dimaksud dengan pelanggaran administrasi adalah pelanggaran terhadap ketentuan dan persyaratan menurut undang-undang. Namun pengertian itu masih sangat luas, sehingga Panwas Pemilu mendefinisikan pelanggaran administrasi adalah pelanggaran terhadap ketentuan persyaratan yang diatur undang-undang dan ketentuan lain yang dibuat penyelenggara Pemilu. Pengertian sebetulnya hanya menegaskan bahwa pelanggaran diluar pelanggaran pidana adalah pelanggaran administrasi, sebab hanya pelanggaran dalam undang-undang Pemilu dalam hal ini UU No. 10 Tahun 2016 Jo UU No. 1 Tahun 2015 Tentang Pemerintahan Daerah yang mengatur tindak pidana dalam Pemilukada yang dapat dikatakan Tindak Pidana Pemilukada, sementara pelanggaran atas keputusan KPU bukan tindak pidana. Begitu pula pelanggaran atas ketentuan dalam KUHP meskipun merupakan tindak pidana, tetapi tidak tergolong tindak pidana pemilu, karena pasal-pasal mengenai tindak pidana pada pemilihan umum yang ada dalam KUHP yang terdiri atas lima pasal sudah tercakup 
dalam UU No. 10 Tahun 2016 Jo UU No. 1Tahun 2015 Tentang Pemerintahan Daerah yang merupakam ketentuan yang lebih khusus. Adapun tindak pidana seperti penganiayaan, perusakan, pembakaran, dan sebagainya meskipun tindak pidana, tetapi diatur dalam KUHP dantidak bisa dikatakan sebagai Tindak Pidana Pemilu dalam hal ini Tindak Pidana Pemilukada.

Perselisihan hasil pemilihan umum, adalah perselisihan antara KPU dan peserta pemilu mengenai penetapan jumlah perolehan suara hasil pemilu secara nasional. Semula ditanggani oleh Mahkamah Agung diserahkan kepada MK. MKtidak hanya terpaku secara harifiah dalam memaknai Pasal 106 ayat (2) UU No. 32 Tahun 2004 Jo UU No. 12 Tahun 2008 Tentang Pemerintahan Daerah dan Pasal 4 Peraturan Mahkamah Konstitusi No. 15 Tahun 2008, yang pada pokoknya menyatakan Mahkamah mengadili perkara Pemilukada terbatas hanya persoalan hasil perolehan suara.

Secara definisipengertian Tindak Pidana Pemilu sulit ditentukan. Sebagaimana yang berlaku bagi terminologi hukum, untuk Tindak Pidana Pemilu juga tidak ada satu rumusan pun yang dapat memberikan secara utuh definisi atau pengertian TindakPidanaPemilu, yang sekaligus dapat dijadikan peganganbakuatau standar bagi semua orang. Namun, demikian salah satu rumusan menjelaskem bahwa "setiap orang, badan hukum, ataupun organisasi yang dengan sengaja melanggar hukum, mengacaukan, menghalang-halangi, atau mengganggu jalannyapemilihan umum yang diselenggarakan menurut undang-undang" merupakan perbuatan pidana pemilu (Prakoso, 1987).

Bahwa yang dimaksud dengan Tindak Pidana Pilkada adalah serangkaian tindak pidana yang diatur secara khusus dalam perundang-undangan. Tindak pidana yang diatur dalam perundang-undangan Pilkada tidak selalu berupa tindak pidana baru yang belum pernah diatur dalam perundang-undangan lain. Beberapa Tindak Pidana Pemilu merupakan tindak pidana yang sebelumnya sudah diatur dalam KUHP. di luar tindak pidana yang diatur dalam perundang-undangan yang mengatur tentang Pilkada masih terdapat berbagai tindak pidana yang dapat terjadi di dalam atau yang berhubungan dengan penyelenggaraan Pilkada.Tindak pidana tersebut bisa dilakukan oleh masyarakat pada umumnya atau oleh peserta Pemilu atau oleh penyelenggara Pemilu.

Secara umum, tindak pidana yang ada di dalam UU No. 10 Tahun 2016 Jo UU No.1 Tahun 2015 Tentang Pemerintahan Daerah untuk memberikan batasan mengenai Tindak Pidana Pilkada. Pembahasan ini mengacu pada ketentuan sebagaimana disebut 
dalam UU No. 10 Tahun 2016 Jo UU No. 1 Tahun 2015 Tentang Pemerintahan Daerah yang dapat dikelompokkan kedalam 3 kategori: 1) Tindak Pidana yang berkenaan dengan penetapan pemilih dan pemenuhan persyaratan peserta Pemilukada; 2) Tindak Pidana yangberkenaan dengan kampanye; 3) Tindak Pidana yang berkenaan dengan pemungutan suara dan hasil pemungutan suara.

\section{Penerapan Ketentuan Tindak Pidana Politik Uang Berdasarkan Undang-undang} No. 10 Tahun 2016

Berdasarkan hasil putusan Hakim terhadap perkara Nomor: 381/Pid.S/2018/PN.Psp, dalam putusannya menyatakan bahwa tindak pidana yang didakwakan Jaksa Penuntut Umum telah terbukti sebagai suatu perbuatan yang merupakan Tindak Pidana Pemilukada sebagaimana catatan tindak pidana yang diatur dalam Pasal 187A ayat (1) UU No. 10 Tahun 2016 Tentang Pemerintaha Daerah yang perumusannya sebagai berikut :

Pasal 187A yang merumuskan :Setiap orang yang dengan sengaja melakukan perbuatan melawan hukum menjanjikan atau memberikan uang atau materi lainnyasebagai imbalan kepada warga negara Indonesia baik secara langsung ataupun tidak langsung untuk mempengaruhi Pemilih agar tidak menggunakan hak pilih, menggunakan hak pilih dengan cara tertentu sehingga suara menjadi tidak sah, memilih calon tertentu, atau tidak memilih calon tertentu sebagaimana dimaksud pada Pasal 73 ayat (4) dipidana dengan pidana penjara paling singkat 36 (tiga puluh enam) bulan dan paling lama 72 (tujuh puluh dua) bulan dan denda paling sedikit Rp200.000.000,00 (dua ratus juta rupiah) dan paling banyak Rp1.000.000.000,00 (satu milyar rupiah).

Berdasarkan hasil penelitian dapat diketahui bahwa yang dimaksud dengan unsur setiap orang disini adalah siapa saja, orang perorangan atau koorporasi atau kumpulan orang baik merupakan badan hukum maupun bukan badan hukum, sebagai subyek hukum selaku pendukung hak dan kewajiban yang mampu mempertanggungjawabkan perbuatannya didepan hukum. Dalam perkara ini Jaksa Penuntut Umum telah menghadapkan terdakwa Ramli Tanjung termasuk sebagai orang perorangan, selaku subyek hukum yaitu pendukung hak dan kewajiban dan selama proses persidangan majelis tidak menemukan adanya alasan pemaaf maupun alasan pembenar yang dapat 
menghapus kesalahan terdakwa sehingga terdakwa Ramli Tanjung mampu untuk mempertanggung jawabkan perbuatannya.

Dari hasil penelitian yang dimaksud unsur dengan sengaja adalah bahwa pelaku ada niat, atau mengetahui, atau menyadari perbuatannya dan menghendaki atau mengetahui akibat yang akan timbul dari perbuatannya. Dalam doktrin ilmu hukum pidana dikenal ada 3 gradasi berkaitan dengan teori kesengajaan, yaitu: a) Kesengajaan sebagai maksud (oogmerek)artinya terjadinya suatu tindakan atau akibat tertentu adalah betul-betul sebagai perwujudan dari maksud atau tujuan dan pengetahuan dari pelaku; b) Kesengajaan sebagai kesadaraan (oopzet bij zekerheids) artinya seberapa jauh pengetahuan atau kesadaran pelaku tentang tindakan dan akibat terlarang yang mungkin akan terjadi; c) Kesengajaan sebagai kemungkinan (dolus evebtualis) artinyasejauh mana pengetahuan atau kesadaraan pelaku tentang tindakan dan akibat terlarang yang mungkin akan terjadi.

Maka dalam perkara a quodikaitkan dengan teori kesengajaan tersebut diatas, maka tepat bila dikatakan kesengajaan yang telah dilakukan oleh terdakwa berada pada gradasi yang pertama, yaitu kategori kesengajaan sebagai maksud, karena dari awal terdakwa telah menyadari/mengetahui atau perbuatannya yaitu dengan sengaja. Menanyakan berapa jumlah DPT dalam rumahsaksi CHAROLLINA ANEKE pada hari minggu tanggal 24juni 2018, karena pada hari senin malam sudah memasuki hari tenang Pemilukada yang melarang untuk melakukan pembagian uang, maka benar majelis menilai sesungguhnya yang terjadi adalah pembagian uang dengan cara memilih salah satu calon Bupati: 1) Unsur "Memberi atau menjanjikan uang atau materi lainnya kepada seseorang supaya tidak mnggunakan hak pilihnya atau memilih pasangan calon tertentu, atau menngunakan hak pilihnya dengan cara tertentu; 2) Unsur "Yang melakukan, menyuruh melakukan, atau ikut melakukan".

Unsur ini pada dasarnya merupakan delik penyertaan sehingga mensyaratkan adanya 2 pelaku atau lebih, setiap pelaku mempunyai peranan dapat sebagai pelaku, yang menyuruh melakukan atau turut serta melakukan perbuatan pidana itu, dimana terdapat kerjasama secara langsung untuk mewujudkan perbuatan pidana tertentu. Menurut Pompe "turut mengerjakan terjadinya sesuatu tindak pidana" itu ada tiga kemungkinan100: a) Mereka masing-masing memenuhi semua unsur dalam rumusan delik; b) Salah seorang memenuhi semua unsur delik, sedang yang lain tidak; c) Tidak 
seorangpun memenuhi unsur-unsur delik seluruhnya, tetapi mereka bersama-sama mewujudkan delik itu, unsur delik pidana yang mencerminkan sikap tidak terpuji dalam Pilkada, berarti telah juga mencederai atau menodai demokrasi.

Dalam putusan, majelis hakim menyatakan bahwa terdakwa RAMLI TANJUNG terbukti secara sah dan meyakinkan bersalah melakukan tindak pidana " Politik Uang yang di dakwakan dengan Pasal 187 A ayat (1) Undang-undang Republik Indonesia Nomor 10 Tahun 2016 tentang perubahan kedua atas Undang-undang Republik Indonesia Nomor 1 tahun 2015 tentang Penetapan Peraturan Pemerintah Pengganti Undang-undang Nomor 1 tahun 2014 tentang Pemilihan Gubernur, Bupati dan Walikota menjadi undang-undang jo pasal 55 ayat (1) ke-1 Kitab Undang-undang Hukum Pidana

Hakim dalam menghadapi perkara hukum ini tidak menjelaskan unsur-unsur yang ada dari Undang-Undang No. 10 Tahun 2016 tentang perubahan kedua atas Undangundang Republik Indonesia Nomor 1 tahun 2015 tentang Penetapan Peraturan Pemerintah Pengganti Undang-undang Nomor 1 tahun 2014 tentang Pemilihan Gubernur, Bupati dan Walikota. Seharusnya hakim bisa dapat menggunakan ilmu bantu seperti menggunakan metode penafsiran hukum apabila hukumnya dinilai tidak jelas dan tidak lengkap. Maksud dari Materi Lainya dalam pasal 187 A ayat 1 UU No. 10 Tahun 2016

Materi lain yang dimaksud tidak ditegaskan secara langsung berupa materi apa saja yang dilarang dalam pemilu pada kasus Politik Uang. Dengan definisi seperti itu sulit diaplikasikan. tetapi hakim menilai perbuatan terdakwa sudah masuk dalam kualifikasi Politik Uang. Tanpa memberikan penjelasan dari unsur-unsur perbuatan pidana dalam Pasal pasal 187 A ayat 1 UU No. 10 Tahun 2016.

Hakim dalam menjatuhkan vonis pidana penjara terhadap Terdakwa tidak didasarkan pada doktrin hukum yang ada yakni apabila hakim merasa kesulitan dalam menemukan hukum atau menjelaskan suatu perbuatan pidana yang dihadapkan padanya, hakim seharusnya dapat menggunakan metode penafsiran hukum, untuk memberikan penjelasan perihal kasus yang di mana dalam penjelasan Undang-Undang No. 10 Tahun 2016 Tentang Pemilihan Gubernur, Bupati, dan Walikota. Pasal 187 A ayat (1) tidak dijelaskan secara jelas. Hakim diberikan kebebasan oleh Undang-Undang dalam menggunakan metode penafsiran hukum apabila hukumnya tidak ada atau kurang jelas, agar tidak ada keragu-raguan dalam memutuskan perkara yang dihadapkannya. 
Kebebasan hakim dalam memberikan putusan sejalan dengan perintah UndangUndang yang mewajibkan hakim sebagai penegak hukum dan keadilan untuk menggali, mengikuti dan memahami nilai-nilai hukum yang hidup dalam masyarakat.Prinsip yang mengatakan bahwa pengadilan tidak boleh menolak untuk memeriksa dan mengadili suatu perkara yang diajukan kepadanya, dengan alasan bahwa hukum tidak ada atau kurang jelas, melainkan wajib untuk memeriksa dan mengadilinya.Prinsip ini didasarkan kepada pandangan bahwa organ pengadilan dapat memahami hukum.

Setiap putusan Hakim harus dapat menunjukan secara tegas ketentuan hukum yang diterapkan dalam suatu perkara yang konkret. Karena hal ini sejalan dengan asas legalitas bahwa suatu tindakan haruslah berdasarkan ketentuan hukum. Asas yang menuntut suatu kepastian hukum bahwa seseorang yang dinyatakan bersalah melakukan suatu perbuatan yang didakwakan kepadanya, memang telah ada sebelumnya suatu ketentuan perundang-undangan yang mengatur perbuatan yang dilarang dilakukan orang. Sehingga segala putusan hakim haruslah memuat alasanalasan dan dasar-dasar putusan itu, untuk dijadikan sabagai dasar dalam mengadili dengan dasar pertimbangan Majelis Hakim dalam memutus perkara terhadap terdakwa, hakim hanya berpatokan pada penjatuhan pidana dan menyatakan sependapat dengan dakwaan yang di ajukan oleh penuntut umum. dan Majelis Hakim meyakini perbuatan Terdakwa memenuhi unsur-unsur dalam Undang-Undang No. 10 Tahun 2016 tentang pemilihan Gubernur, Bupati, dan Walikota Hakim wajib menemukan hukum demi terwujudnya suatu putusan yang adil. Karena dengan melakukan penafsiran hukum, hakim akan dapat menetukan suatu perbuatan pidana yang tidak jelas atau tidak lengkap dalam Undang-Undang. Agar dapat menghasilkan putusan hakim yang dinilai lebih adil dan tidak sewenang-wenang dalam memutus perkara yang dihadapkannya

Berdasarkan gambaran kasus tindak pidana pemilu di atas dengan putusan Nomor: 381/Pid. S./2018/PN.Psp. mempersentasikan berbagai dinamika pemikiran dari waktu ke waktu dengan dilatarbelakangi oleh berbagai kepentingan pada saat itu, yang pada akhirnya kebijakan hukum juga harus berperan sebagai alat untuk mengubah masyarakat ke arah yang lebih baik. Namun dalam putusan akhirnya sedikit menyimpang dari suatu perundang -undangan yang berlaku.Putusan pengadilan diatas hanya diberlakukan masa percobaan (Poeging Delicten) alias terdakwa tidak menjalani kurungan atau hukuman penjara apapun.Pada kasus tindak pidana pemilu hakim telah 
membuat kesepakatan disertakan dengan pertimbangan hukum hakim, pelaksanaan hukumannya hanya percobaan dan denda yang dijatuhkan adalah denda yang hakim lihat dari statusnya dalam masyarakat apakah seseorang tersebut anggota penyelenggara pemilu atau hanya masyarakat biasa (Zebua, Iman, \&Taufik, 2008).

Penyelenggara pemilu menurut Pasal 1 ayat (3) Peraturan Bawaslu nomor 14 Tahun 2012 penyelenggara pemilu adalah lembaga yang menyelenggarakan Pemilu yang terdiri atas Komisi Pemilihan Umum dan Badan Pengawas Pemilu sebagai satu kesatuan fungsi penyelenggaraan Pemilu untuk memilih Kepala Daerah secara langsung oleh rakyat. Mengenai efek jerah untuk pelaku tindak pidana pemilu tidak ada yang dapat menjamin karena pemilu dilakukan hanya 1 (satu) kali dalam5 tahunnya. Intinya ada pada kesadaran terhadap pelaku tersebut, hanya kesadaran diri sendiri yang bisa memberikan teguran untuk tidak mengulangi perbuatannya di pemilu yang akan datang.

Pemahaman tersebut berbeda dengan analisis penulis. salah satu tujuan dari pemidanaan adalah memberikan efek jerah bagi pelaku tindak pidana berbanding terbalik dengan pusan hakim di atas. Seperti halnya hukuman yang diberikan justru berbanding terbalik dengan pasal yang dijatuhkan kepada terdakwa. Pasal 187 yang menegaskan tentang hukuman penjara yang akan dijalani karena telah melanggar pasal tersebut adalah pidana penjara paling singkat 36 (tiga puluh enam) bulan dan paling lama 72 (tujuh puluh dua) bulan dan denda paling sedikit Rp200.000.000,00 (dua ratus juta rupiah) dan paling banyak Rp1.000.000.000,00 (satu milyar rupiah). sedangkan penjatuhan putusan oleh hakim, terdakwahanya menjalani masa percobaan. Dimana pada masa percobaan, terdakwa tidak dapat berbuat tindak pidana dalam bentuk apapun. Hal ini bertolak belakang dengan suatu ketentuan dalam Undang -Undang Nomor 10 Tahun 2016 tentang pemilihan kepala daerah menganggap bahwa hukuman tersebut tidak akan menjamin adanya efek jerah kepada para pelaku tindak pidana pemilu khususnya kepada praktisi pemilu.

Implementasi pemahaman diatas pada prakteknya harus sejalan dengan pembenahan institusi peradilan pemilu, dimana peradilan pemilu kedepannya tidak lagi bersifat ad-hoctetapi permanen.Penerapan ketentuan Undang -Undang harus tegas pemberlakuannya sesuai tindak pidana yang dilakukan dan lebih kepada apabila unsur unsur yang ada pada pasal yang didakwakan terbukti.Dengan demikian penulis mengharapkan adanya perubahan Undang -Undang pilkada yang harus mengakomodir 
alternatif solusi pemahaman tentang aturan hukuman pidananya (hukum materiil) dan penyelarasan hukum acaranya (hukum formiil).Penulis juga memandang bahwa Undang -Undang Nomor 10 Tahun 2016 Penerapan hukum dalam suatu kasus tindak pidana harus lebih memperhatikan arti yang terkandung dalam Undang -Undang.Sebab, masih terdapat potensi masalah pada penegakan hukum atas tindak pidana Pemilukada yaitu berkaitan dengan adanya masa daluarsa, sifat hukuman kumulatif dan tidak adanya hukuman minimal.Oleh karenanyahakim, terutama yang khusus menangani tindak pidana Pemilu sebagai ujung tombak penanganan perkara pidana Pemilu.Hal tersebut menunjang untuk menciptakan keadilan dan kepastian hukum.Karena tindak pidana pemilu merupakan partisipasi warga yang dinilai menyimpang. Dengan demikian, dasar hukum pemilihan umum Kepala daerah yang lebih menjamin lahirnya kepala daearah yang murni karena pilihan masyarakat umum sesuai dengan hati nuraninya.

\section{SIMPULAN}

Pengaturan Tindak pidana Pemilihan Kepala Daerah Dalam Undang-Undang No 10 Tahun 2016 Tentang Pemilihan Kepala Daerah sudah sangat efektif, Dalam hal ini dimana pemberi dan penerima di kenakan sanksi yang sama yang terdapat di dalam pasal 187A jika terbukti melakukan money politic. Proses Penegakan penanganan tindak pidana Pilkada oleh sentra gakkumdu yang merupakan forum kesepahaman yang terdiri dari 3 (tiga) lembaga hukum yakni panwaslu, kepolisian dan kejaksaan. Ketiga lembaga tersebut menangani temuan dan laporan yang telah panwaslu terima sebelumnya dari masyarakat. Sebelum wadah Sentra Gakkumdu terbentuk, ada kesulitan bagi pengawas Pemilu dalam menindaklanjuti temuan atau pelaporan pidana Pemilu. Misalnya, ada beberapa kasus yang diteruskan oleh pengawas Pemilu, tapi ditolak Kepolisian karena dinilai tidak cukup bukti. Potensi pelanggaran pidana Pemilu cukup tinggi dalam setiap tahapan. Dengan demikian, diperlukan satu langkah preventif dan terpadu antara Bawaslu, Polri dan Kejaksaan untuk mengatasi potensi pelanggaran yang mungkin terjadi. Mekanismenya, semua laporan pelanggaran Pemilu akan masuk melalui satu pintu yakni Panwaslu. Kedudukan sentra gakkumdu pada proses penanganan tindak pidana memberikan solusi agar suatu pelanggaran tindak pidana pemilu mendapatkan penanganan yang lebih menjamin suatu kepastian hokum Analisis Hukum Putusan Pengadilan Negri Padang Sidempuan Nomor: 381/pid.Sus/2018/PN.Psp yaitu Tindak 
Pidana Money Politic yang di lakukan Oleh Terdakwa di kualifasikan sebagai suatu bentuk delik formil dan juga delik Ommisi. Mencermati kembali penerapan Ketentuan Tindak Pidana Pilkada berdasarkan UU No.10 Tahun 2016 jo .UU No.1 Tahun 2015 Tentang Pemilihan Gubernur dan Wakil Gubernur, Bupati dan Walikota sudah Tepat. Terhadap putusan yang dijatuhkan Majelis Hakim 12 (bulan) pidana penjara dan denda Rp 200.000.000 (dua ratus juta rupiah), penelitian penegakan menganggap bahwa hukuman tersebut telah tepat akan tetapi tidak memberi efek jera di karnakan pidana tersebut tidak di jalankan.

\section{DAFTAR PUSTAKA}

Hasan, A. (2002). Kamus Besar Bahasa Indonesia, Balai Pustaka, Jakarta, 2002.

Ismawan, I. (1999). Uang Dalam Pemilu. Media Pressindo, Jakarta, 1999.

Mahfud MD, M. (1998). Hukum Dan Pilar-Pilar Demokrasi, Yogyakarta: Penerbit Gama Media.

Mahfud MD, M., (2013). Politik Hukum Di Indonesia, Jakarta: Penerbit Rajawali Pres.

Moeljatno, (2000). Asas-Asas Hukum Pidana, PT. Rineka Cipta, Jakarta.

Nurfitriani, Hamrun, dan Ahmad T., (2017). Pemasaran Politik Bupati Bima Terpilih pada Pilkada Kabupaten Bima Tahun 2015. JPPUMA: JPPUMA: Jurnal Ilmu Pemerintahan dan Sosial Politik UMA (Journal of Governance and Political UMA), 5 (2): 71-78.

Putra, H. (2018). Mendorong Transparansi dan Akuntabilitas Dana Kampanye pada Penyelenggaraan Pilkada Serentak Tahun 2018. JPPUMA: Jurnal Ilmu Pemerintahan dan Sosial Politik UMA (Journal of Governance and Political UMA), 6 (2): 112-121.

Setiadi, A. (2013). PHP (Politik Harahapan Palsu), Yokyakarta: Diva Press, 2013.

Soekanto, S. \& Mamudji. S. (2013). Penelitian Hukum Normatif. Jakarta: Rajawali Pers.

Soekanto, S. (2010). Faktor-Faktor Yang Mempengaruhi Penegakan Hukum, Rajawali Pers, Jakarta.

Suharyanto, A., (2014). Partisipasi Politik Masyarakat Tionghoa dalam Pemilihan Kepala Daerah, JPPUMA: Jurnal Ilmu Pemerintahan dan Sosial Politik UMA (Journal of Governance and Political UMA), 2 (2): 166-175

Sunardian.“Politik-Hitam-Menurut-Para-Filsuf”,website: blogspot.com pada tanggal 8 Januari 2018 Pukul 15: 30 WIB

Suryabrata, S, (1998). Metodelogi Penelitian, PT. RajaGrafindo Persada, Jakarta, 1998.

Undang-Undang DasarNegara Republik Indonesia Tahun 1945.

Undang-Undang No. 1 Tahun 1946 Tentang Kitab Undang-Undang Hukum Pidana.

Undang-Undang No. 8 Tahun 1981 Tentang Kitab Undang-Undang Hukum Acara Pidana.

Undang-Undang Nomor 10 Tahun 2016. Undang-Undang No. 31 Tahun 1999 jo Undang-Undang No. 20 Tahun 2001 Tentang Pemberantasan Tindak Pidana KorupsiUndang-Undang PKPU Nomor 12 Tahun 2015. Perbawaslu No 2 Tahun 2015

Zebua, F.R.P., Iman J., dan Taufik S., (2008), Tanggungjawab Pelaku Tindak Pidana Korupsi dan Ahli Warisnya Dalam Pembayaran Uang Pengganti Kerugian Keuangan Negara Ditinjau Dari Aspek Hukum Perdata (Studi Kasus Pada Pengadilan Negeri Medan), Mercatoria, 1 (2): 150-162 